\title{
In vitro assessment of the capacity of certain mycotoxin binders to adsorb some amino acids and water-soluble vitamins
}

\author{
A. Kihal, ${ }^{1}$ M. Rodriguez-Prado, ${ }^{1}$ C. Godoy, ${ }^{2}$ C. Cristofol, ${ }^{2}$ and S. Calsamiglia ${ }^{1 *}$ (1) \\ ${ }^{1}$ Animal Nutrition and Welfare Service, Departament de Ciència Animal i dels Aliments, Universitat Autònoma de Barcelona, 08193 Bellaterra, \\ Spain \\ ${ }^{2}$ Drug Analysis Service, Departament de Farmacologia, de Terapèutica i de Toxicologia, Universitat Autònoma de Barcelona, 08193 Bellaterra, \\ Spain
}

\section{ABSTRACT}

The objective of this study was to evaluate the capacity of 6 mycotoxin binders (MTB) to adsorb 3 AA and 4 water-soluble vitamins (WSV). Two experiments were conducted in in vitro conditions to simulate postruminal digestion with pepsin, malic acid, citric acid, acetic acid, and lactic acid at $\mathrm{pH} 3.0$ and intestinal digestion with bile salts and pancreatin extract at $\mathrm{pH}$ 6.5. Experiment 1 was conducted with AA, and experiment 2 was conducted with WSV. Within experiment, main factors were the MTB (bentonite, clinoptiolite, sepiolite, montmorillonite, activated carbon, and yeast cell walls), the substrate (AA: Lys, Met, and Thr; WSV: $\mathrm{B}_{1}, \mathrm{~B}_{2}, \mathrm{~B}_{3}$, and $\mathrm{B}_{6}$ ), and the incubation strategy (substrates alone or mixed). Data were analyzed for the effects of main factors and their interactions. In experiment 1 , the adsorption average for AA when incubated separately was $44.3 \%$, ranging from $62.4 \%$ for Thr by clinoptiolite to $20.0 \%$ for Thr by activated carbon. When incubated together, the average adsorption was reduced to $19.9 \%$, suggesting competition among substrates for adsorption. Adsorption ranged from $29.8 \%$ for Thr by yeast cell walls to $5.6 \%$ for Met by clinoptiolite, but there were significant interactions among MTB and AA. In experiment 2, the average adsorption of WSV when incubated separately or together was 34.1 and $45.1 \%$, respectively, suggesting possible synergies among substrates. When vitamins were incubated separately, adsorption ranged from $90.5 \%$ for vitamin $\mathrm{B}_{1}$ to $4.0 \%$ for vitamin $\mathrm{B}_{3}$ by montmorillonite. Vitamins $\mathrm{B}_{1}$ (except by yeast cell walls) and $\mathrm{B}_{6}$ (except by bentonite, sepiolite, and montmorillonite) were absorbed the most, and vitamin $\mathrm{B}_{3}$ was absorbed the least (except by activated carbon and yeast cell walls, which were least together with vitamin $\mathrm{B}_{2}$ ). When vitamins were incubated to-

Received September 8, 2019.

Accepted November 23, 2019.

*Corresponding author: Sergio.Calsamiglia@uab.cat gether, adsorption ranged from $97.0 \%$ for vitamin $\mathrm{B}_{1}$ by montmorillonite to $0 \%$ for vitamin $\mathrm{B}_{2}$ by activated carbon and vitamin $B_{3}$ by bentonite. Vitamins $B_{1}$ by all MTB and $B_{6}$ by clinoptiolite, sepiolite, and yeast cell walls were the most adsorbed, and vitamin $B_{3}$ (except by activated carbon and yeast cell wall) was the least absorbed. There were significant interactions among MTB and WSV. Mycotoxin binders have a high degree of adsorption of the AA and WSV tested in in vitro conditions, which may limit their bioavailability. Results also suggest that when substrates were incubated together some interactions for adsorption occurred, which were competitive among AA and synergic among vitamins.

Key words: mycotoxin binder, adsorption, amino acid, vitamin

\section{INTRODUCTION}

Mycotoxins are secondary metabolites of molds produced under unfavorable climate conditions and during handling, transportation, or storage of feeds and represent a potential risk for animal and human health (Yiannikouris and Jouany, 2002; Jouany et al., $2005)$. Currently, more than $65 \%$ of the food produced worldwide is contaminated with mycotoxins (Biomin, 2019). Mycotoxins may affect feed intake, production performance, reproduction, and the immune system (Lubulwa and Davis, 1994; Akande et al., 2006), resulting in high economic losses for the livestock industry (Yiannikouris and Jouany, 2002; CAST, 2003).

Mycotoxin binders (MTB) are among the primary strategies to control the negative effects of mycotoxins when they are already present in the gastrointestinal tract of animals. The binding capacity depends on the molecular size, structure, and weak ionic interactions between organic molecules and MTB (Phillips et al., 1990; Jouany et al., 2005). Thus, this interaction may be selective depending on the MTB and the mycotoxin. For example, Huff et al. (1992) reported that hydrated sodium calcium aluminosilicates reduced the toxicity 
of aflatoxins but not that of ochratoxin in chicks. Diaz et al. (2004) reported that the adsorption capacity of bentonite for aflatoxins varies among different mine sources. Yeast cell walls have high adsorption affinity for zearalenone (Jouany et al., 2005), and the addition of yeast cell walls to diets reduced aflatoxin residues in milk (Diaz et al., 2004).

The specificity and the affinity of MTB depend on the molecular size, structure, and charge interactions between MTB and ligands. Certain organic compounds such as fatty acids, amines, AA, vitamins, and aromatic compounds have similar molecular weight, structure, or charges as mycotoxins. This may make it possible for MTB to adsorb these dietary compounds (Lagaly et al., 2013). Vekiru et al. (2007) reported that the presence of nutrients (proteins, enzymes, and vitamins) in the gastric juice reduced the adsorption of mycotoxins by 15\%. Barrientos-Velázquez et al. (2016) also observed an interaction between bentonite and the adsorption of vitamin $\mathrm{B}_{1}$ and aflatoxins. Similar results were reported by Joshi et al. (2009) where montmorillonite adsorbed vitamin $B_{1}$. As the adsorption mechanism of clays is through a cation exchange of small molecules, other clay-based binders may also interfere with nutrients in the gastrointestinal tract. However, no studies have tested different AA and vitamins for adsorption by different types of MTB.

We hypothesized that MTB may adsorb nutrients of relatively small molecular weight such as AA and vitamins with different affinities depending on the type of MTB. The aim of this work was to assess the capacity of different MTB to adsorb AA and vitamins using an in vitro postruminal digestion model.

\section{MATERIALS AND METHODS}

\section{Incubations and Treatments}

In vitro experiments were carried out using an adaptation of the technique described by Lemke et al. (2001) and Gallo and Masoero (2010). Incubations were conducted in triplicate and in 2 consecutive periods. Samples were incubated in $100-\mathrm{mL}$ tubes containing 50 $\mathrm{mL}$ of the gastric digestion solution; prepared with 1.25 g/L pepsin (77160, Sigma-Aldrich, St. Louis, MO), 0.5 $\mathrm{mL}$ of malic acid, $42 \mu \mathrm{L} / \mathrm{L}$ lactic acid, $0.5 \mathrm{~g} / \mathrm{L}$ citric acid, and $50 \mu \mathrm{L} / \mathrm{L}$ acetic acid; and adjusted at $\mathrm{pH} 3.0$. Tubes were incubated in a water bath at $37^{\circ} \mathrm{C}$ for $2 \mathrm{~h}$ and shaken with a vortex at the start of the incubation and at 1-h intervals until the end of the incubation. After $2 \mathrm{~h}$, the $\mathrm{pH}$ was neutralized to 6.5 with $2 \mathrm{~mL}$ of sodium bicarbonate solution $(8.8 \mathrm{~g} / 100 \mathrm{~mL})$ and $2 \mathrm{~mL}$ of a second solution containing $3.5 \mathrm{~g} / 100 \mathrm{~mL}$ bile salts (48305, Sigma-Aldrich) and $1 \mathrm{~g} / 100 \mathrm{~mL}$ pancreatin
(P7545, Sigma-Aldrich) to simulate intestinal digestion. The incubation continued under the same conditions for an additional $2 \mathrm{~h}$.

Two experiments were conducted according to the type of substrate: experiment 1 with $\mathrm{AA}$ and experiment 2 with water-soluble vitamins (WSV). Within each experiment, main factors were the MTB (bentonite, clinoptiolite, sepiolite, montmorillonite, activated carbon, and yeast cell walls), the substrate (experiment 1: Lys, Met, and Thr; experiment 2: vitamins $\mathrm{B}_{1}, \mathrm{~B}_{2}, \mathrm{~B}_{3}$, and $\mathrm{B}_{6}$ ), and the incubation strategy (substrates alone or together). The substrates evaluated in experiment 1 (AA) were Lys (98.5\% purity; Meihua Group, Kowloon, Hong Kong), Thr (98.5\% purity; Meihua Group), and Met (99\% purity; Evonik, Isernhagen, Germany). Lysine and Met were selected because they are the main limiting AA, and Thr was selected because, being an essential AA, it contains a side chain with a hydroxyl group. Lysine also contains positive charges in its 2 amino groups. The substrates evaluated in experiment 2 (WSV) were vitamins $\mathrm{B}_{1}$ (thiamine mononitrate, $99.8 \%$ purity; DSM Nutritional Products, Ruma, Serbia), $\mathrm{B}_{2}$ (riboflavin, 82\% purity; Kaesler Nutrition, Cuxhaven, Germany), $\mathrm{B}_{3}$ (niacinamide, 99\% purity; Shandong Kunda Biotechnology, Shandong, China), and $\mathrm{B}_{6}$ (pyridoxine hydrochloride, $99.9 \%$ purity; Kaesler Nutrition). The WSV were selected because they have a similar molecular weight compared with many mycotoxins $\left(\mathrm{B}_{1}\right.$ and $\mathrm{B}_{2}$ ) or have similar molecular weight compared with AA but contain a different number of hydroxyl groups ( 1 and 3 for vitamins $\mathrm{B}_{3}$ and $\mathrm{B}_{6}$, respectively). The dose of MTB was calculated according to its use in field conditions $(2 \mathrm{~kg} / \mathrm{t})$. The MTB to AA or WSV ratio was calculated to be similar to that found in physiological conditions (NRC, 2001; Calsamiglia and Rodriguez-Prado, 2012). Doses of MTB were $100 \mathrm{mg}$ of each MTB. The doses of substrates were as follows: 100 $\mathrm{mg}$ of Lys, Thr, and Met; $0.15 \mathrm{mg}$ of vitamin $\mathrm{B}_{1} ; 0.50$ $\mathrm{mg}$ of vitamin $\mathrm{B}_{2} ; 4.0 \mathrm{mg}$ of vitamin $\mathrm{B}_{3}$; and $0.25 \mathrm{mg}$ of vitamin $\mathrm{B}_{6}$. All incubations included a blank consisting of the buffer without MTB or substrates and a positive control with buffer and each substrate but not MTB. Within each assay, substrates were incubated separately or together within type of substrate.

\section{Sampling, Processing, and Analyses}

At the end of the incubation process, subsamples of each individual tube were taken and centrifuged at $7,000 \times g$ for $15 \mathrm{~min}$ at $5^{\circ} \mathrm{C}$, and the resulting supernatant was frozen at $-20^{\circ} \mathrm{C}$ until analysis of the AA and vitamin concentrations. For the analysis of AA, $200 \mu \mathrm{L}$ of each subsample was diluted with $800 \mu \mathrm{L}$ of deionized water. Then, $5 \mu \mathrm{L}$ of each diluted sample 
was placed in glass vials for the AA derivatization with fluorenylmethoxycarbonyl at $\mathrm{pH} 8.5$ for $20 \mathrm{~min}$ at room temperature. The derivatization reaction was stopped with $200 \mu \mathrm{L}$ of glycine solution $(7.5 \mathrm{mg} / \mathrm{mL}$ of water). The concentrations of AA in samples were analyzed using HPLC with fluorometric detection of the fluorenylmethoxycarbonyl derivatives of each AA. Amino acid samples were separated using a $5-\mu \mathrm{m}$ reversed-phase chromatography ultrabase column $(200 \times$ $4.6 \mathrm{~mm}$ i.d., AKADY, Barcelona, Spain). The column was maintained at $50^{\circ} \mathrm{C}$, and the flow rate was set to $1.5 \mathrm{~mL} / \mathrm{min}$. The HPLC mobile phase was acetonitrile $0.1 \%$ phosphoric acid in water in a solvent gradient as follows. The initial conditions were $28 \%$ acetonitrile and $72 \%$ phosphoric acid; after injection, the conditions linearly changed to $72: 28$ for 15 min and returned to the initial conditions in $0.1 \mathrm{~min}$. The total sample running time was $18.5 \mathrm{~min}$. An Agilent (Darmstadt, Germany) 1100 system equipped with an autosampler (Agilent G1330A), a quaternary pump (Agilent G1311A), and a fluorometric detector (Agilent G1321A) was used for AA quantification. Data were processed using an IBM (Armonk, NY) computer with ChemStation software (Agilent). Substrates were detected at 254- and 313-nm excitation and wavelength emission, respectively. Under these conditions, the retention times of the derivatives of Thr, Met, and Lys were 8.35, 11.6, and $16.16 \mathrm{~min}$, respectively.

For the quantification of WSV, $1 \mathrm{~mL}$ of each sample was placed in an Eppendorf tube and centrifuged at $20,000 \times g$ for $10 \mathrm{~min}$ at $4^{\circ} \mathrm{C}$. A $200-\mu \mathrm{L}$ aliquot of each sample was diluted with $200 \mu \mathrm{L}$ of methanol and 400 $\mu \mathrm{L}$ of Milli-Q water (MilliQ Water Purification System, Molsheim, France). Then, the samples were shaken in a multivortex for $5 \mathrm{~min}$ and centrifuged at 7,000 $\times$ $g$ for $10 \mathrm{~min}$ at $4^{\circ} \mathrm{C}$. A $100-\mu \mathrm{L}$ aliquot was placed in HPLC vials for analysis. The quantification of WSV was performed with a reversed-phase HPLC technique with tandem MS detection of triple quadrupole. Watersoluble vitamin samples were separated using a $1.8-\mu \mathrm{m}$ Zorbax SB-C18 column $(150 \times 4.6 \mathrm{~mm}$ i.d., Agilent $)$ and a 1260 series HPLC (Agilent). The column was maintained at $30^{\circ} \mathrm{C}$, and the flow rate was set to 0.3 $\mathrm{mL} / \mathrm{min}$. The HPLC mobile phase was methanol $0.1 \%$ formic acid and water $0.1 \%$ formic acid in a solvent gradient condition as follows. The initial conditions were 20:80 MetOH:water; for 3 min the conditions changed to 80:20 and were maintained for $1 \mathrm{~min}$ at 80:20 and then returned to initial conditions. The total run time was $12 \mathrm{~min}$. Substrates were detected with an MS-QQQ detector (Agilent G6420) with electrospray ionization source in positive mode. The quantified transitions were 265.1 to 144 for vitamin $\mathrm{B}_{1}, 377.1$ to 243.1 for vitamin $\mathrm{B}_{2}, 123.1$ to 80.1 for vitamin $\mathrm{B}_{3}$, and 170.1 to 152.1 for vitamin $\mathrm{B}_{6}$. Under these conditions, the retention times were $4.1,5.1,6.3$, and $9.1 \mathrm{~min}$ for vitamins $\mathrm{B}_{1}, \mathrm{~B}_{3}, \mathrm{~B}_{2}$, and $\mathrm{B}_{6}$, respectively.

For the sample quantification (AA or WSV), a calibration sample set (5 levels) was prepared and analyzed each day of analysis. Calibration samples were prepared with a blank matrix spiked with increasing known concentrations of each substrate. A linear regression calibration curve was calculated between the peak area and the calibration sample concentration. Sample substrate concentration was calculated after interpolation of the peak area into the calibration curve. In addition, each day of analysis, a quality control sample set (triplicate) was prepared at 3 levels of the calibration curve to accept the results of the analytical series.

The adsorption index was calculated as the difference between the concentration of each substrate of the positive control without MTB and the corresponding treatment concentration of the substrate incubated with the MTB as

$$
\text { adsorption index }=(\mathrm{Ci}-\mathrm{Ct}) \times 100 / \mathrm{Ci} \text {, }
$$

where $\mathrm{Ci}$ is the initial concentration of the positive control $(\mathrm{mg} / \mathrm{mL})$ and $\mathrm{Ct}$ is the treatment concentration of the unbound substrate with MTB $(\mathrm{mg} / \mathrm{mL})$ from the corresponding positive control of the substrate studied. The adsorption index was expressed as a percent of the substrate bound to the MTB.

\section{Statistical Analyses}

Within each experiment, AA and WSV adsorption results were analyzed using PROC MIXED of SAS (version 9.4; SAS Institute Inc., Cary, NC). Within each experiment (AA or WSV), the model included as fixed effects the MTB, the substrates (each AA or WSV), the incubation strategy (individual vs. mixed substrates), and their interactions. The experimental period was the random effect. Results are presented as least squares means. When the difference between means was significant $(P<0.05)$, the comparison of means was made using the Tukey test and separated using the SLICEBY option of PROC PLM of SAS.

\section{RESULTS}

Main effects, the interaction between MTB and substrates, and the 3 -way MTB $\times$ substrates $\times$ incubation strategy interactions were significant. The 3 -way interaction is difficult to present in a $6 \times 3 \times 2$ and $6 \times 4$ $\times 2$ factorial design. Therefore, results of the MTB $\times$ substrate interaction are shown in separate tables when incubated alone or together. 
Table 1. Adsorption index of the 6 mycotoxin binders with the 3 AA when incubated separately

\begin{tabular}{|c|c|c|c|c|c|c|}
\hline \multirow[b]{2}{*}{$\mathrm{AA}$} & \multicolumn{6}{|c|}{ Mycotoxin binder ${ }^{1}$} \\
\hline & Bentonite & Clinoptiolite & Sepiolite & MMT & $\mathrm{AC}$ & YCW \\
\hline $\begin{array}{l}\text { Lysine } \\
\text { Methionine } \\
\text { Threonine } \\
\text { SEM }\end{array}$ & $\begin{array}{l}28.3^{\mathrm{b}, \mathrm{x}} \\
51.9^{\mathrm{w}} \\
53.6^{\mathrm{ab}, \mathrm{w}} \\
4.08\end{array}$ & $\begin{array}{l}36.1^{\mathrm{ab}, \mathrm{x}} \\
50.7^{\mathrm{w}} \\
62.4^{\mathrm{a}, \mathrm{w}}\end{array}$ & $\begin{array}{l}31.2^{\mathrm{b}, \mathrm{x}} \\
41.4^{\mathrm{wx}} \\
48.1^{\mathrm{b}, \mathrm{w}}\end{array}$ & $\begin{array}{l}47.0^{\mathrm{a}, \mathrm{wx}} \\
40.0^{\mathrm{x}} \\
53.1^{\mathrm{b}, \mathrm{w}}\end{array}$ & $\begin{array}{l}38.4^{\mathrm{ab}, \mathrm{x}} \\
50.4^{\mathrm{w}} \\
20.0^{\mathrm{c}, \mathrm{y}}\end{array}$ & $\begin{array}{l}38.7^{\mathrm{ab}, \mathrm{x}} \\
47.8^{\mathrm{wx}} \\
58.4^{\mathrm{ab}, \mathrm{w}}\end{array}$ \\
\hline
\end{tabular}

\section{AA Adsorption}

The average adsorption index of AA when incubated separately was $44.3 \%$. Within MTB, average adsorption ranged from $49.7 \%$ in clinoptiolite to $36.3 \%$ in activated carbon. Within AA, average adsorption ranged from $49.3 \%$ in Thr and $36.6 \%$ in Lys. There was an MTB $\times$ AA interaction in adsorption index (Table 1). Differences were significant between $\mathrm{Thr}$ and Met versus Lys in bentonite and clinoptiolite, between $\mathrm{Thr}$ versus Lys in sepiolite and yeast cell walls, between Thr versus Met in montmorillonite, and between Thr versus Met versus Lys in activated carbon. Threonine was less adsorbed by activated carbon compared with the other binders. Lysine was less adsorbed by bentonite and sepiolite compared with montmorillonite. No difference was observed in the adsorption of Met among binders.

The average adsorption index of AA when incubated together $(19.9 \%)$ was lower than when incubated separately $(44.3 \%)$ and ranged from $27.6 \%$ in montmorillonite to $12.6 \%$ in clinoptiolite. Within AA, average adsorption ranged from $22.4 \%$ in Thr to $16.0 \%$ in Met. There was an MTB $\times$ AA interaction in adsorption index (Table 2). Within MTB, differences were significant between Lys and Met in clinoptiolite. Threonine was less adsorbed in clinoptiolite compared with montmorillonite, activated carbon, and yeast cell walls. Lysine was less adsorbed by clinoptiolite and bentonite compared with montmorillonite. Methionine was less adsorbed by bentonite, clinoptiolite, and sepiolite compared with montmorillonite and yeast cell walls.

\section{WSV Adsorption}

The average adsorption index for WSV when incubated separately was $34.1 \%$ and ranged from an average of $56.4 \%$ in montmorillonite to $18.0 \%$ in activated carbon. Among WSV, average adsorption ranged from $52.8 \%$ for vitamin $\mathrm{B}_{1}$ to $5.4 \%$ for vitamin $\mathrm{B}_{3}$. The MTB $\times$ WSV interaction for adsorption index was significant (Table 3). Vitamin $B_{1}$ was adsorbed the highest by bentonite and montmorillonite and the lowest by activated carbon and yeast cell walls. Vitamin $\mathrm{B}_{2}$ was absorbed the highest by montmorillonite and the lowest by clinoptiolite, activated carbon, and yeast cell wall. Vitamin $\mathrm{B}_{3}$ adsorption was very low (average of $5.4 \%$ ) and not different among MTB. Vitamin $\mathrm{B}_{6}$ was absorbed the highest by montmorillonite. Bentonite had the highest affinity for vitamin $\mathrm{B}_{1}$ and lowest affinity for vitamin $\mathrm{B}_{3}$. Clinoptiolite, sepiolite, and activated carbon had the highest affinity for vitamins $\mathrm{B}_{1}$ and $\mathrm{B}_{6}$. Clinoptiolite and sepiolite had the lowest affinity for vitamin $\mathrm{B}_{3}$, and activated carbon had the lowest affinity for vitamins $\mathrm{B}_{2}$ and $\mathrm{B}_{3}$. Montmorillonite had the highest affinity for vitamin $B_{1}$. Yeast cell walls had the highest affinity for vitamin $\mathrm{B}_{6}$ and the lowest affinity for vitamin $\mathrm{B}_{3}$.

Table 2. Adsorption index of the 6 mycotoxin binders with the 3 AA when incubated together

\begin{tabular}{|c|c|c|c|c|c|c|}
\hline \multirow[b]{2}{*}{$\mathrm{AA}$} & \multicolumn{6}{|c|}{ Mycotoxin binder ${ }^{1}$} \\
\hline & Bentonite & Clinoptiolite & Sepiolite & MMT & $\mathrm{AC}$ & YCW \\
\hline Lysine & $15.7^{\mathrm{cd}}$ & $18.6^{\mathrm{bcd}, \mathrm{w}}$ & $14.7^{\mathrm{d}}$ & $28.8^{\mathrm{a}}$ & $24.4^{\mathrm{abc}}$ & $25.7^{\mathrm{al}}$ \\
\hline Methionine & $9.9^{\mathrm{c}}$ & $5.6^{\mathrm{c}, \mathrm{x}}$ & $11.9^{\mathrm{bc}}$ & $24.9^{\mathrm{a}}$ & $20.0^{\mathrm{ab}}$ & $23.5^{\mathrm{a}}$ \\
\hline Threonine & $17.1^{\mathrm{bc}}$ & $13.6^{\mathrm{c}, \mathrm{wx}}$ & $19.0^{\mathrm{bc}}$ & $29.2^{\mathrm{a}}$ & $25.6^{\mathrm{ab}}$ & $29.8^{\mathrm{a}}$ \\
\hline SEM & 3.32 & & & & & \\
\hline
\end{tabular}


Table 3. Adsorption index of the 6 mycotoxin binders with 4 water-soluble vitamins when incubated separately

\begin{tabular}{|c|c|c|c|c|c|c|}
\hline \multirow{2}{*}{$\begin{array}{l}\text { Water-soluble } \\
\text { vitamin }\end{array}$} & \multicolumn{6}{|c|}{ Mycotoxin binder ${ }^{1}$} \\
\hline & Bentonite & Clinoptiolite & Sepiolite & MMT & $\mathrm{AC}$ & YCW \\
\hline $\mathrm{B}_{1}$ & $83.6^{\mathrm{a}, \mathrm{w}}$ & $50.2^{\mathrm{b}, \mathrm{w}}$ & $49.0^{\mathrm{b}, \mathrm{w}}$ & $90.5^{\mathrm{a}, \mathrm{w}}$ & $23.5^{\mathrm{c}, \mathrm{w}}$ & $19.9^{\mathrm{c}, \mathrm{x}}$ \\
\hline $\mathrm{B}_{2}$ & $52.7^{\mathrm{b}, \mathrm{x}}$ & $18.0^{\mathrm{d}, \mathrm{x}}$ & $32.9^{\mathrm{c}, \mathrm{x}}$ & $67.7^{\mathrm{a}, \mathrm{x}}$ & $8.0^{\mathrm{d}, \mathrm{x}}$ & $17.3^{\mathrm{d}, \mathrm{xy}}$ \\
\hline $\mathrm{B}_{3}$ & $8.0^{\mathrm{y}}$ & $4.2^{\mathrm{y}}$ & $5.4^{\mathrm{y}}$ & $4.0^{\mathrm{y}}$ & $5.5^{\mathrm{x}}$ & $5.0^{\mathrm{y}}$ \\
\hline $\mathrm{B}_{6}$ & $49.2^{\mathrm{ab}, \mathrm{x}}$ & $35.8^{\mathrm{b}, \mathrm{w}}$ & $43.4^{\mathrm{b}, \mathrm{wx}}$ & $63.4^{\mathrm{a}, \mathrm{x}}$ & $34.9^{\mathrm{b}, \mathrm{w}}$ & $45.7^{\mathrm{b}, \mathrm{w}}$ \\
\hline SEM & 5.03 & & & & & \\
\hline
\end{tabular}

${ }^{\mathrm{a}-\mathrm{d}}$ Different superscripts in the same row indicate a significant effect between binders $(P<0.05)$.

${ }^{\mathrm{w}-\mathrm{y}}$ Different superscripts in the same column indicate a significant effect between vitamins $(P<0.05)$.

${ }^{1} \mathrm{MMT}=$ montmorillonite; $\mathrm{AC}=$ activated carbon; $\mathrm{YCW}=$ yeast cell wall.

The average adsorption index for WSV when incubated together $(46.1 \%)$ was higher than when incubated separately (34.1\%). Average adsorption was highest in montmorillonite $(60.5 \%)$ and lowest in activated carbon (33.5\%). Among WSV, average adsorption was highest for vitamin $\mathrm{B}_{1}(78.4 \%)$ and lowest for $\mathrm{B}_{3}(4.1 \%)$. There was a significant MTB $\times$ WSV interaction in the adsorption index when WSV were incubated together (Table 4). Bentonite had the highest affinity for vitamin $B_{1}$ and the lowest affinity for $\mathrm{B}_{3}$. Clinoptiolite and sepiolite had the highest affinity for vitamins $B_{1}$ and $\mathrm{B}_{6}$ and the lowest affinity for $\mathrm{B}_{3}$. Montmorillonite and activated carbon had the highest affinity for vitamin $B_{1}$ and the lowest affinity for $\mathrm{B}_{3}$ and $\mathrm{B}_{2}$, respectively. Yeast cell walls had the highest affinity for vitamin $B_{1}$ and $B_{6}$ and the lowest affinity for $\mathrm{B}_{2}$ and $\mathrm{B}_{3}$. Vitamin $\mathrm{B}_{1}$ adsorption was highest in bentonite and montmorillonite and lowest in yeast cell walls. Adsorption of vitamin $\mathrm{B}_{2}$ was highest in montmorillonite and lowest in activated carbon. The average adsorption of vitamin $\mathrm{B}_{3}$ was low (4.1\%), with small differences among MTB. Adsorption of vitamin $\mathrm{B}_{6}$ was high (65.7\%), but with small differences among MTB (ranged from 59.2 to $72.1 \%$ ).

\section{DISCUSSION}

Mycotoxin binders are used in animal industry to reduce the negative effects of mycotoxins in contaminated feeds. A wide diversity of mechanisms of action explain the variable adsorption capacity of MTB in front of different mycotoxins. Current understanding relates the adsorption capacity to a combination of factors including molecular size, structure, and the capacity to establish weak chemical bonds between the mycotoxin and the binder (Deng et al., 2010; Deng and Szczerba, 2011). These mechanisms of action are often unspecific and thus may adsorb other nutrients (McLaren et al., 1958; Pinck, 1962; Lagaly et al., 2013; BarrientosVelázquez et al., 2016). For example, the molecular weight of aflatoxin, vomitoxin, zearalenone, and nivalenol is around $300 \mathrm{~g} / \mathrm{mol}(312,296,318$, and $312 \mathrm{~g} /$ mol, respectively) and is greater for ochratoxin, ergot, and fumonisin (403, 581, and $721 \mathrm{~g} / \mathrm{mol}$, respectively). The molecular weights of Lys, Met, Thr, vitamin $\mathrm{B}_{3}$, and vitamin $\mathrm{B}_{6}(147,149,119,127$, and $169 \mathrm{~g} / \mathrm{mol}$, respectively) are smaller than mycotoxins, and the molecular weights of vitamins $\mathrm{B}_{1}$ and $\mathrm{B}_{2}(265$ and $376 \mathrm{~g} /$ mol, respectively) are closer to most mycotoxins. In the present experiment, average adsorption of AA (44.3\%, ranging from 20.0 to $62.4 \%$ ) and WSV (34.1\%, ranging from 4.0 to $91.5 \%$ ) was within the range and variability observed for the adsorption capacity for mycotoxins (Calsamiglia and Kihal, 2019). This occurred for AA even considering that their molecular weight was much lower than that of mycotoxins. Kollár et al. (2003) also observed that adsorption of protonated AA, including

Table 4. Adsorption index of the 6 mycotoxin binders with 4 water-soluble vitamins when incubated together

\begin{tabular}{|c|c|c|c|c|c|c|}
\hline \multirow{2}{*}{$\begin{array}{l}\text { Water-soluble } \\
\text { vitamin }\end{array}$} & \multicolumn{6}{|c|}{ Mycotoxin binder ${ }^{1}$} \\
\hline & Bentonite & Clinoptiolite & Sepiolite & MMT & $\mathrm{AC}$ & YCW \\
\hline$\overline{\mathrm{B}_{1}}$ & $94.2^{\mathrm{a}, \mathrm{w}}$ & $74.6^{\mathrm{b}, \mathrm{w}}$ & $73.4^{\mathrm{b}, \mathrm{w}}$ & $97.0^{\mathrm{a}, \mathrm{w}}$ & $70.3^{\mathrm{bc}, \mathrm{w}}$ & $60.7^{\mathrm{c}, \mathrm{w}}$ \\
\hline $\mathrm{B}_{2}$ & $55.3^{\mathrm{ab}, \mathrm{x}}$ & $35.3^{\mathrm{c}, \mathrm{x}}$ & $50.9^{\mathrm{b}, \mathrm{x}}$ & $66.0^{\mathrm{a}, \mathrm{x}}$ & $0.0^{\mathrm{e}, \mathrm{z}}$ & $9.2^{\mathrm{d}, \mathrm{x}}$ \\
\hline $\mathrm{B}_{3}$ & $0.0^{\mathrm{b}, \mathrm{y}}$ & $1.0^{\mathrm{ab}, \mathrm{y}}$ & $8.3^{\mathrm{a}, \mathrm{y}}$ & $7.0^{\mathrm{ab}, \mathrm{y}}$ & $4.3^{\mathrm{ab}, \mathrm{y}}$ & $4.2^{\mathrm{ab}, \mathrm{x}}$ \\
\hline $\mathrm{B}_{6}$ & $62.2^{\mathrm{ab}, \mathrm{x}}$ & $66.6^{\mathrm{ab}, \mathrm{w}}$ & $67.0^{\mathrm{ab}, \mathrm{w}}$ & $72.1^{\mathrm{a}, \mathrm{x}}$ & $59.2^{\mathrm{b}, \mathrm{x}}$ & $66.9^{\mathrm{ab}, \mathrm{w}}$ \\
\hline SEM & 4.41 & & & & & \\
\hline
\end{tabular}

${ }^{\mathrm{a}-\mathrm{e}}$ Different superscripts in the same row indicate a significant effect between binders $(P<0.05)$.

${ }^{\mathrm{w}-\mathrm{z}}$ Different superscripts in the same column indicate a significant effect between vitamins $(P<0.05)$.

${ }^{1} \mathrm{MMT}=$ montmorillonite $\mathrm{AC}=$ activated carbon; $\mathrm{YCW}=$ yeast cell wall. 
Lys and Met, by montmorillonite was high. The adsorption of AA into clays is associated with their zwitterion state, where they have a positive and a negative charge (dipole). When incubated separately, there were large differences in adsorption among AA and MTB, ranging from $20.0 \%$ in activated carbon to $62.4 \%$ in clinoptiolite for Thr. Threonine has the lowest molecular weight among the AA tested, but the hydroxyl group may have contributed to establishing additional binding sites, resulting in higher adsorption. Methionine has a larger molecular weight but no hydroxyl groups to help increase binding, yet adsorption was similar to that of Thr, except by montmorillonite and activated carbon. In contrast, Lys had the lowest adsorption in bentonite, clinoptiolite, and sepiolite despite similar molecular weight compared with Met. Because the size of AA was much smaller than that of mycotoxins and were different among AA, differences in adsorption cannot be justified by differences in molecular weight. In most cases, the binding sites of MTB contain cations, which are effective binders for anions. Then, hydroxyl groups, present in Thr, may have enhanced adsorption, whereas the 2 positive charges in the form of amino groups in Lys may have reduced its adsorption. Although the changes in molecular weight and differences in charges among the AA tested were small, they may justify the differences in adsorption by different MTB. Mortland and Lawless (1983) reported that small changes in the interlayer space in $\mathrm{Na}^{+}$bentonite $(\sim 20 \AA)$ compared with $\mathrm{Ca}^{2+}$ bentonite $(\sim 15.0 \AA)$ were sufficient to change the physical space or the distance for a stable ionic interaction and modify the adsorption capacity of clays. Adsorption of the 3 AA by yeast cell walls and Lys and Met by activated carbon was not much different from that of clays. The adsorption of mycotoxins by yeast cell walls depends on the $\beta$-D-glucans inner layer that binds mycotoxins based on their geometrical form, electron bonds between aromatic cycle and glucose units, and H-bonding with hydroxyl groups (Jouany et al., 2005). Threonine has low molecular weight, but the hydroxyl group may have contributed to the high adsorption by yeast cell walls. In contrast, adsorption of Thr by activated carbon was lower than that of other MTB. The mechanism of adsorption of activated carbon is attributed to the weak interactions between aromatic groups of mycotoxins and the hydrophobic environment of activated carbon (Sánchez et al., 2012). Activated carbon bounds mycotoxins into pores whose size is much larger than the interlayer space of clays: the interlayer space of clays is measured in angstroms, whereas the pores in the activated carbon are measured in nanometers (Galvano et al., 2001; Sethia and Sayari, 2016). It is possible that Thr is too small to establish bonds within these large pores of activated carbon; however, Met and Lys are only slightly larger but adsorption was relatively high (50 and $38 \%$, respectively) despite the 2 cations in the form of amino groups in Lys.

When AA were incubated together, the average adsorption of the 3 AA decreased from 44.3 to $19.9 \%$, suggesting that the interaction was competitive in the conditions of the test. The average adsorption was reduced by 69,74 , and $62 \%$ for bentonite, clinoptiolite, and sepiolite, respectively, compared with montmorillonite, activated carbon, and yeast cell walls, where adsorption was reduced by 41,36 , and $46 \%$, respectively. Amino acids adsorption decreased 58, 34, and $16 \%$ for Lys, Met, and Thr, respectively. Methionine went from the highest adsorption when incubated alone to the lowest when incubated together with the other AA. Results suggest that Met was bound to MTB through weak links and was displaced easier when there was competition with other AA. The MTB $\times$ substrate $\times$ incubation strategy was significant (statistical output not shown). However, the interpretation of the 3-way interaction is difficult and complex. Tables for the MTB $\times$ substrate interaction for incubation of substrates alone or mixed are provided (Tables 1 and 2) for consideration of such interactions, but they are not discussed in detail herein. Overall, results suggest that the incubation of the $3 \mathrm{AA}$ together may result in a competition among them and saturate the adsorption sites of MTB, excluding the ones with weaker affinity.

One mechanism of action of the adsorption of nutrients into MTB is the presence of hydroxyl or carbonyl groups to allow ionic interactions. Except vitamin $\mathrm{B}_{3}$, the WSV tested do not contain any of these groups. However, vitamins have aromatic rings that allow binding with $\beta$-D-glucans of yeast cell walls. We initially hypothesized that higher molecular weight of vitamins $\mathrm{B}_{1}$ and $\mathrm{B}_{2}$ and the structure with 3 aromatic rings cycles would result in higher adsorption by yeast cell walls and activated carbon and less by clays compared with AA. Therefore, we also hypothesized that because vitamins $B_{1}$ and $B_{2}$ had similar molecular weight compared with most mycotoxins, their adsorption would be higher compared with $\mathrm{AA}$ or vitamins $\mathrm{B}_{3}$ and $\mathrm{B}_{6}$. However, this was not true, and therefore molecular weight could not explain differences in the adsorption of vitamins among MTB. Vitamins $\mathrm{B}_{3}$ and $\mathrm{B}_{6}$ have similar molecular weight, yet vitamin $\mathrm{B}_{6}$ has more hydroxyl groups for binding compared with vitamin $\mathrm{B}_{3}$ (3 vs. 1 hydroxyl group, respectively). We hypothesized that the hydroxyl groups would increase the binding affinity. In fact, vitamin $\mathrm{B}_{6}$ had a higher adsorption index than vitamin $\mathrm{B}_{3}$, likely due to the differences in the number of hydroxyl groups. In our study, vitamins $B_{1}$ (except in yeast cell walls) and $\mathrm{B}_{6}$ (except in bentonite and montmorillonite) had higher adsorption than the other 
vitamins, and vitamin $\mathrm{B}_{3}$ always had the lowest. It may be hypothesized that because of the small size, WSV can get into the interlayer space of clays and form stable bonds. Joshi et al. (2009) and Barrientos-Velázquez et al. (2016) observed similar result in the adsorption of vitamin $\mathrm{B}_{1}$ in bentonite and montmorillonite. Mortland and Lawless (1983) studied the adsorption of vitamin $\mathrm{B}_{2}$ in the presence of 2 types of bentonite $\left(\mathrm{Ca}^{2+}\right.$ and $\mathrm{Na}^{+}$). Results showed that $\mathrm{Na}^{+}$bentonite adsorbs more $\mathrm{B}_{2}$ than $\mathrm{Ca}^{2+}$ bentonite. Authors associated this difference with the higher interlayer space in $\mathrm{Na}^{+}$bentonite $(\sim 20 \AA)$ compared with $\mathrm{Ca}^{2+}(\sim 15.0 \AA)$, which allows the adsorption of $\mathrm{B}_{2}$ based on its molecular size. Similar results were observed for vitamin $B_{1}$, which has a similar structure. Vitamin $\mathrm{B}_{3}$ had very low adsorption by all MTB. Although it is tempting to attribute this low adsorption to its small molecular weight, it is similar to Thr in molecular weight and structure, so there is no clear explanation for these differences. However, it adds evidence to the fact that molecular weight and structure are only contributors to the binding affinity, and other factors should also be involved. As observed in AA, the average adsorption of WSV in activated carbon was low, likely due to the fact that pores are too large to allow for sufficiently strong ionic interactions. The binding mechanism of action of yeast cell walls has been attributed to the interaction with aromatic organic compounds. Vitamins $\mathrm{B}_{1}$ and $\mathrm{B}_{2}$ contain 3 aromatic rings suitable for such interactions, but adsorption was only intermediate for $\mathrm{B}_{1}(23.5 \%)$ and low for $\mathrm{B}_{2}(8 \%)$ compared with the other vitamins. The adsorption of vitamin $\mathrm{B}_{3}$ was also very low in yeast cell walls. The molecular structure of vitamin $\mathrm{B}_{3}$ is similar to that of vitamin $\mathrm{B}_{6}$ and smaller than that of vitamins $\mathrm{B}_{1}$ and $\mathrm{B}_{2}$. It includes a carbonyl group and only 1 aromatic ring, so we cannot explain the lower adsorption of vitamin $\mathrm{B}_{3}$ compared with vitamins $\mathrm{B}_{1}$ and $\mathrm{B}_{6}$ based on its molecular structure. Also, it is not clear why some MTB adsorb some vitamins more than others even when they have similar molecular structure (for example, vitamins $\mathrm{B}_{1}$ vs. $\mathrm{B}_{2}$ ).

When WSV were incubated together, adsorption increased from 34.1 to $45.6 \%$, increasing mainly in clinoptiolite, sepiolite, activated carbon, and yeast cell walls $(160,153,184$, and $164 \%$, respectively). The adsorption of vitamins $\mathrm{B}_{1}(147 \%)$ and $\mathrm{B}_{6}(145 \%)$ also increased compared with their adsorption when incubated separately. The MTB $\times$ substrate $\times$ incubation strategy was significant (statistical output not shown). However, the interpretation of the 3-way interaction is difficult and complex. Tables for the MTB $\times$ substrate interaction for incubation of substrates alone or mixed are provided (Tables 3 and 4) for consideration of such interactions, but they are not discussed in detail herein.
The increase in adsorption when WSV were incubated together has no clear explanation but was consistent across vitamins and MTB except for vitamin $B_{3}$. It can be only speculated that the combination of WSV results in synergies among WSV and possibly other nutrients that increase their adsorption when incubated together. Further studies are warranted to explore the extent and the implications of these possible synergies.

The high adsorption and interactions for the adsorption sites of MTB observed in our experiment are intriguing. A possible competition for binding sites may also occur among mycotoxins and other nutrients, which in turn may also reduce the adsorption of mycotoxins. In contrast, results also suggested synergies among WSV that may also occur among other nutrients. Because of all these interactions, it is difficult to explain their effect on nutrient utilization and mycotoxin binding in physiological conditions, but it raises some relevant questions on the use of MTB. Lysine and Met are recognized first-limiting AA in dairy cattle, and there are major efforts in developing rumen-protected sources to increase its supply to the small intestine (Schwab and Broderick, 2017). Therefore, any potential interference with absorption may compromise these efforts. The effect of the availability of WSV is more difficult to assess. Although supplementation with vitamin $\mathrm{B}_{3}$ (niacin) to dairy cows in the peripartum period may improve performance (Schwab et al., 2005), vitamin $\mathrm{B}_{3}$ is among the least affected by MTB adsorption. The other B-vitamins used in the present study are not supplemented to dairy diets, and production by rumen microbes is thought to be sufficient to supply requirements (Calsamiglia and Rodriguez-Prado, 2012). However, if MTB adsorption is high it may compromise their bioavailability; this deserves further research. The current study has, on one hand, the merit of highlighting some potentially relevant interactions but, on the other hand, has some major limitations. The in vitro test was conducted in a clean buffer solution and, because of evidence of interactions, the behavior of MTB in a complex matrix such as the small intestinal fluid may be different. This may affect the bioavailability of some nutrients but may also limit the ability of MTB to adsorb mycotoxins. More research should be carried out to evaluate the implications of the relevant interaction of MTB with nutrients using gastric juice or in vivo conditions, where more nutrients are implicated.

\section{CONCLUSIONS}

The in vitro test was used to assess the capacity of 6 MTB to adsorb AA and vitamins. Amino acids had the highest adsorption rate among substrates tested, followed by WSV. When AA were incubated together, the 
adsorption capacity of MTB was reduced by half due to competition among AA for binding sites. However, the adsorption of WSV increased when they were incubated together, suggesting synergies among vitamins. The significant 3-way interaction needs to be considered in the interpretation of results. Further research is necessary to evaluate these interactions among AA and vitamins for the adsorption sites of MTB and the implications on the adsorption capacity of mycotoxins. This research should also consider the interaction with other nutrients found in physiological conditions of the digestive tract.

\section{ACKNOWLEDGMENTS}

The authors have not stated any conflicts of interest.

\section{REFERENCES}

Akande, K. E., M. M. Abubakar, T. A. Adegbola, and S. E. Bogoro. 2006. Nutritional and health implications of mycotoxins in animal feeds: A review. Pak. J. Nutr. 5:398-403. https://doi.org/10.3923/ pjn.2006.398.403.

Barrientos-Velázquez, A. L., S. Arteaga, J. B. Dixon, and Y. Deng. 2016. The effect of $\mathrm{pH}$, pepsin, exchange cation, and vitamins on aflatoxin adsorption on smectite in simulated gastric fluids. Appl. Clay Sci. 120:17-23. https://doi.org/10.1016/j.clay.2015.11.014.

Biomin. 2019. The global mycotoxin threat 2019. Accessed Nov. 10, 2019. https://www2.biomin.net/es/imagenes/the-global -mycotoxin-threat-2019-infographic/.

Calsamiglia, S., and A. Kihal. 2019. Los adsorbents de micotoxinas como estrategia de control de micotoxinas en las raciones: Tipos, eficacia e interacciones. Pages 29-47 in Proc. V Joranda FEDNAANEMBE, Madrid, Spain. ANEMBE, Oviedo, Spain.

Calsamiglia, S., and M. E. Rodriguez-Prado. 2012. Optimum vitamin nutrition in dairy cattle. Pages 335-385 in Optimum Vitamin Nutrition in the Production of Quality Animal Foods. A. C. Barroeta, M. D. Baucells, A. Blanco, S. Calsamiglia, R. Casals, R. Cepero, R. Davin, G. Gonzalez, J. M. Hernández, B. Isabel, C. Lopez Bote, I. A. Rey, M. Rodriguez, J. Sanz, M. F. Soto-Solanova, and G. Weber, ed. 5M Publishing, Sheffield, UK.

CAST (Council for Agriculture Science and Technology). 2003. Mycotoxins: Risks in plant, animal, and human systems. Task force report no. 139. CAST, Ames, IA.

Deng, Y., A. L. Barrientos Velázquez, F. Billes, and J. B. Dixon. 2010. Bounding mechanisms between aflatoxin $\mathrm{B}_{1}$ and smectite. Appl. Clay Sci. 50:92-98. https://doi.org/10.1016/j.clay.2010.07.008.

Deng, Y., and M. Szczerba. 2011. Computational evaluation of bounding between aflatoxin $\mathrm{B}_{1}$ and smectite. Appl. Clay Sci. 54:26-33. https://doi.org/10.1016/j.clay.2011.07.007.

Diaz, D. E., W. M. Hagler Jr., J. T. Blackwelder, J. A. Eve, B. A. Hopkins, K. L. Anderson, F. T. Jones, and L. W. Whitlow. 2004. Aflatoxin binders II: Reduction of aflatoxin M1 in milk by sequestering agents of cows consuming aflatoxin in feed. Mycopathologia 157:233-241. https://doi.org/10.1023/b:myco.0000020587.93872 .59 .

Gallo, A., and F. Masoero. 2010. In vitro models to evaluate the capacity of different sequestering agents to adsorb aflatoxins. Ital. J. Anim. Sci. 9:e21. https://doi.org/10.4081/ijas.2010.e21.

Galvano, F., A. Piva, A. Ritieni, and G. Galvano. 2001. Dietary strategies to counteract the effect of mycotoxins: A review. J. Food Prot. 64:120-131. https://doi.org/10.4315/0362-028x-64.1.120.

Huff, W. E., L. F. Kubena, R. B. Harvey, and T. D. Phillips. 1992. Efficacy of hydrated sodium calcium aluminosilicate to reduce the individual and combined toxicity of aflatoxin and ochratoxin A. Poult. Sci. 71:64-69. https://doi.org/10.3382/ps.0710064.

Joshi, G. V., H. A. Patel, B. D. Kevadiya, and H. C. Bajaj. 2009. Montmorillonite intercalated with vitamin $\mathrm{B}_{1}$ as drug carrier. Appl. Clay Sci. 45:248-253. https://doi.org/10.1016/j.clay.2009.06 .001 .

Jouany, J. P., A. Yiannikouris, and G. Bertin. 2005. How yeast cell wall components can alleviate mycotoxicosis in animal production and improve the safety of edible animal products. J. Anim. Sci 14(Suppl. 1):171-190. https://doi.org/10.22358/jafs/70361/2005.

Kollár, T., I. Palinko, Z. Konya, and I. Kiricsi. 2003. Intercalating amino acid guests into montmorillonite host. J. Mol. Struct. 651653:335-340. https://doi.org/10.1016/S0022-2860(03)00109-1.

Lagaly, G., M. Ogawa, and I. Dékány. 2013. Clay mineral-organic interactions. Pages 435-505 in Developments in Clay Science. Handbook of Clay Science Vol. 5. https://doi.org/10.1016/B978-0-08 -098258-8.00015-8.

Lemke, S. L., S. E. Ottinger, K. Mayura, C. L. Ake, K. Pimpukdee, N. Wang, and T. D. Phillips. 2001. Development of a multi-tiered approach to the in vitro pre-screening of clay-based enterosorbents. Anim. Feed Sci. Technol. 93:17-29. https://doi.org/10.1016/S0377 $-8401(01) 00272-3$

Lubulwa, A. S. G., and J. S. Davis. 1994. Estimating the social costs of the impacts of fungi and aflatoxins in maize and peanuts. Pages 1017-1042 in Proc. 6th International Working Conference on Stored-Product Protection. CAB International, Wallingford, UK.

McLaren, A. D., G. H. Peterson, and I. Barshad. 1958. The adsorption and reactions of enzymes and proteins on clay minerals: IV. Kaolinite and montmorillonite. Soil Sci. Soc. Am. J. 22:239-244. https://doi.org/10.2136/sssaj1958.03615995002200030014x.

Mortland, M. M., and J. G. Lawless. 1983. Smectite interaction with riboflavin. Clays Clay Miner. 31:435-439. https://doi.org/10.1346/ CCMN.1983.0310604.

NRC. 2001. Nutrient Requirements of Dairy Cattle. National Academy Press, Washington, DC.

Phillips, T. D., B. A. Clement, L. F. Kubena, and R. B. Harvey. 1990. Detection and detoxification of aflatoxins: Prevention of aflatoxicosis and aflatoxin residues with hydrated sodium calcium aluminosilicate. Vet. Hum. Toxicol. 32(Suppl.):15-19.

Pinck, L. A. 1962. Adsorption of proteins, enzymes and antibiotics by montmorillonite. Pages 520-529 in Clays and Clay Minerals: Proc. 9th National Conference on Clays and Clay Minerals. A Swineford, ed. Pergamon Press, New York, NY.

Sánchez, R. C., J. C. Martorell, and E. C. Baldoví. 2012. Neutralización de micotoxinas por sustancias adsorbentes. Nereis 4:77-88.

Schwab, C. G., and G. A. Broderick. 2017. A 100-year review: Protein and amino acid nutrition in dairy cows. J. Dairy Sci. 100:1009410112. https://doi.org/10.3168/jds.2017-13320.

Schwab, E. C., D. Z. Caraviello, and R. D. Shaver. 2005. Review: A meta-analysis of lactation responses to supplemental dietary niacin in dairy cows. Prof. Anim. Sci. 21:239-247. https://doi.org/10 .15232/S1080-7446(15)31214-6.

Sethia, G., and A. Sayari. 2016. Activated carbon with optimum pore size distribution for hydrogen storage. Carbon 99:289-294. https:/ /doi.org/10.1016/j.carbon.2015.12.032.

Vekiru, E., S. Fruhauf, M. Sahin, F. Ottner, G. Schatzmayr, and R. Krska. 2007. Investigation of various adsorbents for their ability to bind aflatoxin $\mathrm{B}_{1}$. Mycotoxin Res. 23:27-33. https://doi.org/10 $.1007 / \mathrm{BF} 02946021$.

Yiannikouris, A., and J. P. Jouany. 2002. Mycotoxins in feed and their fate in animals: A review. Anim. Res. 51:81-99. https://doi.org/10 .1051/animres:2002012.

\section{ORCIDS}

S. Calsamiglia @ https://orcid.org/0000-0002-0978-3799 